\title{
Modern garden delphiniums
}

\author{
SHIRLEY E. BASSETT
}

\section{Resum}

Bassett, S. E. (1990). Els delphiniums de jardineria moderns. Collect. Bot. (Barcelona) 19: $153-160$

Es descriuen les característiques dels delphiniums híbrids de jardi anglesos moderns. Es discuteix el desenvolupament de la raça de granes «Pacific» a Amèrica per Reinelt $\mathrm{i}$ l'èxit de la introducció de colors vermells a Holanda per Legro. L'evolució dels híbrids de jardineria tetraploides és considerada a la llum de les espècies que eren disponibles per als primers milloradors. Es revisa el paper de la Delphinium Society en la promoció de la flor i en la promoció dels programes de millora.

Mots clau: Delphinium, Jardineria, Millora genètica, Hibridació, Poliploïdia.

\begin{abstract}
Bassett, S. E. (1990), Modern Garden Delphiniums. Collect Bot. (Barcelona) 19: 153-160.

The characteristic features of modern English garden hybrid delphiniums are described. The development by Reinelt of the "Pacific»seed strain in America, and the successful introduction of red colours by Legro in Holland are discussed. The evolution of the tetraploid garden hybrid is considered in the light of species available to early breeders. The role of the Delphinium Society in the promotion of the flower and the encouragement of breeding programmes is reviewed.
\end{abstract}

Keywords: Delphinium, Gardening, Plant breeding, Polyploidy.

For many years cultivars of the perennial garden Delphinium have been favourite flowers in the English herbaceous border. Today they are available in a wide range of colour from white, cream, shades of blue, lavender, purple and dusky pink, and in heights varying from $3 \mathrm{ft}$ $(1 \mathrm{~m})$ to $8-9 \mathrm{ft}(2.5-3 \mathrm{~m})$, although 5-6 ft (1.8-2 m) plants are now more popular. Absent at present are the true reds and brilliant yellow seen in D. cardinale Hook. and D. zalil Aitch Hemsl. although attempts to introduce the former have been the work for some thirty years of Dr. R. A. H. Legro with considerable success. No longer can it be said «Geraniums red and Delphiniums blue» but the brilliant blue seen in D. grandiflorum L. and $D$. tatsiense Franch.

S.E. BASSETT: The Delphinium Society, «Takakkaw», Ice House Wood, Oxted, Surrey, RH8 9DW, England. 
is lacking in the average modern cultivar, being marred by either pink colouration at the base of the sepals or by purple at the tips.

In the years from 1928, the Delphinium Society has attempted to promote the growing of the best semi-double delphiniums available and to eliminate the poorer single-flowered forms from gardens. In association with the Royal Horticultural Society, trials are run at the Wisley gardens to enable the public to assess the perfomance of named cultivars and become aquainted with the work of present-day breeding, now largely in the hands of a few dedicated amateurs.

\section{Characteristics of Modern Garden Hybrids}

In order to be clear about the desirable characteristics of modern hybrid delphiniums, as recognised in the United Kingdom and N. America, a description is necessary since they differ significantly from species growing throughout the Northern Hemisphere and N. Africa, and from types widely cultivated in parts of Europe. The newly-planted seedling gives rise to a single raceme or flower spike, after which the base of the plant develops a solid central crown from which arise lateral buds. Each of these lateral buds will give rise to a single flowering stem. Survival of these buds from the predation of slugs and snails leads over the years to a plant of considerable size, capable of producing, if allowed, an excessive number of flowering shoots. Basal leaves are large, roundish in outline and partially divided into 5 or 7 sections each with further incisions and toothed edges. Leaves are generally smooth on the upper surface and with a varying density of hairs on the under side. Nearer the flowers, the leaves become reduced to 3 sections. Individual cultivars show much variability and can be recognised on their leaf characteristics.

In contrast to the older cultivars, the flowers occupy the upper 3-4 $\mathrm{ft}(1-1.3 \mathrm{~m})$ of the total $5-6 \mathrm{ft}(1.8-2 \mathrm{~m})$ stem with a change from the earlier flat-topped cylindrical spike to a spike with a broader base tapering to the apex. To achieve this symmetrical appearance, each floret is carried on a long pedicel which decreases in length towards the apex. The florets are arranged in a spiral such that each expanded floret is just touching its adjacent fellows. The coarse fleshy stem found in older cultivars has been replaced by a stronger slimmer stem, but which still needs support even in dwarf cultivars, to avoid breakage at the base of the stem in bad weather. Below the main flower spike develop a number of lateral flower stems, prolonging the display of colour. Cultivars vary in the number and length of these lateral stems, a character selected by breeders depending on the eventual use of the plant as a garden or exhibition cultivar.

The most important feature of the modern hybrid delphinium is the form of the floret. The 5 sepals (one with a long spur) of the wild-type single flower have been replaced by a minimum of 13 sepals, 5 outer and 8 inner rounded flat sepals often with a frilly edge to the inner set, giving a semi-double flower. The spur remains but is considerably reduced. The corolla or "eye» has at least 4 petals and often more, and may be in a contrasting white, black or self colour. It is neat with the nectar-producing spur petals buried in the calyx spur. The lower petals bear white or yellow hairs, a reminder of the species $D$. elatum L. from which the garden forms were derived. These florets are at least 2.5 inches $(7 \mathrm{~cm})$ in diameter and over 3 inches $(9 \mathrm{~cm})$ in the best cultivars. The flowers are protandrous with numerous stamens and generally 3-5 or occasionally more, carpels.

Cultivars with an increased number of sepals are found giving a double-flowered appearance, while loss of stamens and a further increase in petal number can be seen in «ranunculustype» sterile flowers, without a spur. This change in form of floret from single to semi-double has been accompanied by the longer-lasting qualities of the flowers. The bottom florets no longer set seed and shed their sepals/petals before the flower buds are open even half-way up 
the raceme. In good modern cultivars, florets are open from base to apex before any sepals/petals are shed. Indeed some cultivars retain their sepals long after the carpels have developed.

\section{Origins of Some Garden Hybrids}

Despite the fact that conditions over the winter months in Great Britain do not resemble those of the high mountains of the widely-distributed $D$. elatum L. so that crown of the plant may have to endure early warmth and wet conditions mixed with colder drier periods, breeding in the United Kingdom has concentrated on the development of relatively longlived perennials. Some cultivars have remained in our garden for over fourteen years in one position although the lifetime before deterioration is shorter in some named cultivars. Howerer in the United States of America, the most notable breeder of recent times, (1930-1965) Frank Reinelt, developed the "Pacific» strain of delphiniums. This was a strain designed to offer American gardeners a series of individual colours comparatively true from seed. This difference of approach was due firstly to recognition of the range of climatic conditions in the United States, and secondly, to the problems of aster virus yellows spread by Thrips and black crown rot, probably Sclerotinia Rolfsii (REINELT, 1964). He achieved a clarity of colour in this series of blues, «Blue Bird», "Blue Jay» and «Summer Skies» rarely seen in the present British named cultivars. Sadly, the production of a seed strain true to colour in delphiniums requires more effort than just allowing open-pollination among plants grown in colour blocks. Reinelt achieved his strains by alternately selecting the best plants of a colour and handpollinating between them and then allowing the resultant offspring to hybridise freely among themselves in the next generation.

The colours available to Reinelt from the United Kingdom at the beginning of his breeding programme were mainly blues, lavender and violet shades, bi-colours of blue and mauve and a few creams. Creams had arisen in the late 1890s and were always rather weak plants characterised by the bronzing of the foliage and flower stems. True white flowers, although present in Belladonna delphiniums, where a pale blue cultivar «Capri» threw three white spikes which were vegetatively propagated as «Moerheimi», did not appear in garden hybrid delphiniums until Charles Barber in Oregon, U.S.A. introduced his "Hoodacre Whites» around 1930. Seed from one of these, a cultivar named «Pearl Necklace», laid the foundations of Reinelt's white Pacific strains, the "Galahad» series (white sepals and white petals) and later the «Percival» series where the petals are black.

In common with so many other delphinium breeders, Reinelt wished to introduce pink and red colours to his seed strains. Until 1941, the only well-documented pink was Ruys' "Pink Sensation" introduced in 1936, although the rosy pinks found in the annual larkspurs derived from Consolida ajacis (L.) Schur and C. regalis S.F. Gray were well known and had been grown since Elizabethan times in England. D. ruysii hort. ex Ruys, 1934 «Pink Sensation» was the result of some thirty years of hybridisation by Mr Ruys of the Royal Moerheim Nurseries, Dedemsvaart, Holland, who attempted to cross D. elatum hybrids with the dwarf orange and red $D$. nudicaule Torr. et Gray. As D. elatum hybrids are tetraploid and D. nudicaule a diploid, his efforts were, as would be expected, unsuccessful. However it would appear that a chance increase in ploidy occurred among a large number of plants of $D$. nudicaule and crosspollination by $D$. elatum plants in the vicinity led to one purple seedling with single florets on a $4.5 \mathrm{ft}(1.5 \mathrm{~m})$ raceme. Selection of seedlings from this plant gave four scarlet plants which were used in further hybridisation and selection to give «Pink Sensation». Aware of this information, Reinelt embarked on a long programme which was to lead to the dusky-pink «Astolat» series introduced in 1951.

In the «Astolat» series the sepal colour, noted by the raiser to be «diluted magenta» due to 
its derivation from delphinidin, varies from pale lilac pink to deep raspberry rose with brown or black petals. Starting from the tall scarlet $D$. cardinale, Reinelt X-rayed the seeds with a view to determining the lethal dose. He recorded that the «most fruitful was a batch X-radiated for 40 minutes», one seed only germinating to give an apparently normal $D$. cardinale (REINELT, 1964). However the F1 from selfing gave a variety of types in heights from 4 in to $8 \mathrm{ft}(10 \mathrm{~cm}$ $2.8 \mathrm{~m}$ ) with generally distorted growth, but with some flowers twice the normal size. These "giants" were the beginning of a tetraploid race which would give viable hybrids with his garden «Pacific» strain. Although the seedlings resulting from the use of «giant» D. cardinale were of varying colours from lavender to wine-violet, the quality of colour had been changed from a rather dull matt to a velvety brilliance. This influence can be seen still today in many of our named cultivars. More importantly, crossing "giant» cardinale seedlings with white «Pacific» plants led to pink tinges in the sepals and eventually to selection for the pinks of the "Astolat» range and the later "Elaine» series, with pale pink sepals with white petals.

Although other Americans, notably Mehlquist and Samuelson worked with D. cardinale and $D$. nudicaule, the successful introduction of red into plants resembling garden $D$. elatum hybrids came from the work commenced in 1953 by Dr. R. A. H. Legro in the University of Wageningen (1979). Today we have the promise of a new race of garden hybrid delphiniums in a wide range of red-derived colours, pinks, apricots and scarlet. He started in a rather similar way, obtaining tetraploid $D$. nudicaule and $D$. cardinale after the use of colchicine. However although overcoming the difference in ploidy between the diploid species and the tetraploid garden delphiniums, when either $D$. cardinale or $D$. nudicaule tetraploids were used as pollen parents, further incompatibility appeared. Use of tetraploid $D$. nudicaule as the seed parent led to viable seed, but no appearance of semi-double flowers or red/orange colour in large numbers of plants of the F2 generation.

Crosses were then made between $D$. nudicaule $\mathrm{x} D$. cardinale at the diploid level and the resultant seedlings treated with colchicine to give allotetraploids. The few allotetraploids that were obtained in this way were fully self-fertile, the remaining diploids were not. Again, only the use of the new alloploids as seed parents led to fertile and plentiful seed. This production of the amphidiploid was the successful step, since the F2 generation from a cross between the tetraploid nudicaule/cardinale and the garden elatum showed both orange/red colour and semi-double florets. From 1957 a continuous programme of hybridisation and selection in Holland, and of later years, at the Royal Horticultural Society garden at Wisley, has resulted in a race of plants in a range of colours with «elatum-like» characteristics of a long raceme with semi-double or double "carnation-like» florets and good foliage. Problems still exist in two major areas; low viability of seed which can be improved by cold, wet treatment similar to that given to seeds of alpines, and a rootstock which is still too much like that of the red species, failing to produce many crown buds and difficult to propagate vegetatively. Use of tissue culture techniques for propagation, although not easy in the Ranunculaceae, may provide a means of making these plants available commercially. An additional problem is the susceptibility to mildew seen in the original species parents. The length of time taken on these experiments, so familiar to geneticists, does not readily lead to commercial viability. Blackmore and Langdon, long established in the delphinium world in England, although commencing work with material from Mehlquist and Legro and obtaining some interesting variations in colour, abandoned the whole attempt on the basis of development costs.

\section{Chromosomal Status of Garden Hybrids}

One of the barriers to the use of other species in breeding garden hybrids has been the possession of 32 chromosomes $(4 x)$ in the latter compared with $16(2 x)$ in the species. The origins of the garden hybrid and how it came by this tetraploidy are unclear. Numerous efforts have been made to trace the evolution of the garden delphinium, not least by WILDE (1930) 
who concluded that «their exact origin is obscure». It would seem unlikely that now, some sixty years later, additional documentary evidence would come to light.

A number of points can be made in order to assess the available evidence. Certainly the annual larkspurs $C$. ajacis and $C$. regalis were known to the Elizabethans and Stuarts in the sixtenth and seveteenth centuries, in both single and double forms and a variety of colours. On the continent of Europe, D. staphisagria L. and D. peregrinum L. were known to the early Greeks and Romans. Clusius in 1601 is thought to be the first to mention D. elatum as Aconitum Lycoctonum flore Delphinij Silesiacum (WILDE, 1930). Through the next two hundred years, increasing numbers of Delphinium sp. were described and added to the list, although many appear to be synonyms, understandable in the light of communication difficulties at that time. It seems that seed of $D$. elatum, $D$. grandiflorum and $D$. grandiflorum var chinense was available in Europe and Great Britain and listed in catalogues such as that of Vilmorin-Andrieux in the 1820 s. D. grandiflorum as described would seem to be a very variable plant, sometimes with a loose raceme of 3-4 ft (1-1.3 m), other times a low branching type, $1 \mathrm{ft}(30 \mathrm{~cm})$ in height, and both forms could have either single or double flowers.

Two plants should be mentioned, D. barlowii introduced by a nurseryman for a $\mathrm{Mr}$. Barlow of Manchester, England in 1837 and a few years later, D. formosum raised by $\mathrm{Mr}$. Moore of Norfolk, England. D. barlowii hort ex Lindley, 1837, (nom. nud.), described as having semi-double dark-blue flowers, was a supposed hybrid of $D$. grandiflorum with $D$. elatum and should probably more correctly be called $D$. grandiflorum var barlowii. D. formosum seems to have been the basis of a great deal of misconception since it is described as a hybrid perennial coming true from seed. It appears to have possessed a compact raceme with flowers deep-blue tinged violet in colour and to have produced triangular winged seeds. The true species D. formosum Boiss. \& Huet. was not described until 1856 and has a branching habit, dark purple flowers and scaly seeds. WILDE (1930) believes that $D$. formosum hort. may be a form of $D$. cheilanthum Fisch. described in 1824 from Siberia and probably available but not listed by a European Seed House until 1880.

The original D. belladonna hort ex Flor. Cabinet, 1857, (nom. nud.) was also grown for many years, appearing in Kelway's (England) list of 1881, and is another type of garden delphinium with unknown origins. It has single, relatively large flowers borne on branching stems and is quite different in appearance to the $D$. elatum hybrids. The early plants of «Belladonna» were sterile, but around 1902-3, growers appear to have obtained a few seeds which then led to the introduction of more varieties including the white mutation, "Moerheimii», mentioned earlier. Investigations by MEHLQUIST (1963) showed that the sterile plants were triploids with $2 n=24$ chromosomes, while the more fertile appeared to be hexaploids with $2 n=48$ chromosomes. Experiments with D. elatum «Pacific» strain and D. grandiflorum var chinense led to triploids which after colchicine treatment gave a few seeds and fertile hexaploids. Rather similar results were obtained with $D$. elatum $($ Pacific) $\times D$. tatsienense. Since some seeds of $D$. tatsienense were sent originally to Vilmorin in 1895 by the Abbé Farge, it would appear more likely that the original «Belladonna» was a chance hybrid between D. elatum (garden form) and D. grandiflorum var. chinense. Of interest is a comment by KNIGHT (1960) who raised and introduced «Bonita», a plant with lovely single gentian blue florets. In 1940 he noticed this plant with poor elatum form among a batch of seedlings grown from seed saved from open-pollinated garden elatum. He did not known the origin of this belladonna-like plant, but comments that in his garden at the time were plants of $D$. grandiflorum var. chinense. WILDE (1930) cohich suggests that the original «Belladonna» was a chance hybrid between $D$. elatum and $D$. cheilanthum Fisch., although there is no evidence that the latter was widely grown in gardens. It is certainly not available as seed at the present time in England in contrast to forms of $D$. grandiflorum. Wilde was also unaware of the triploid status of the original plant.

If any of these diploid species were involved in the original hybrid "Belladonna», then it is suggesting that $D$. elatum was already tetraploid in 1881 , since the cross would involve a 
diploid gamete $(2 n) \times$ a haploid gamete $(1 n)$. Thus the problem of the origins of the garden elatum hybrids will not be an easy one to solve. Difficulties arise because there were a number of synonyms in use and the early introducers of new varieties such as Vilmorin and Lemoine gave their plants apparent botanical names. The first hybrid elatum appeared about 1848, and in 1852 Lemoine obtained the first double variety which he called "D. ornatum", later followed by such varieties as $" D$. cheiranthiflorum» and "D. bellidiflorum». In answer to a questionnaire sent out by WILDE (1930), V. Lemoine \& Sons stated that only three species entered into the development of their strains, D. elatum, D. formosum and D. tatsienense. Yet $D$. tatsienense was not described until 1893 and the true D. formosum Boiss. \& Huet until 1856, so that $D$. elatum remains as the true species, together with $D$. formosum hort.

It seems to me that the answer might be forthcoming from a consideration of cytogenetics. The argument really involves distinguishing whether the garden elatum is an auto- or allotetraploid. It would not appear worthwhile for any of the early breeders to introduce diploid species. The fact that they had to hybridise probably reflects a problem well known to anyone who tries to cross the semi-double flower with a single-flowered elatum. Singles can still be found in gardens and sometimes appear in a batch of seedlings. The single-flowered form is dominant and all the seedlings from such a cross will be single-flowered. The semi-double character will then only reappear in the F2 at low frequency, 1 in 36 or 1 in 22 depending on the position of the gene involved in relation to the centromere (S.E. BASSETT, unpubl. data). Even if these early breeders did not have the advantage of understanding Mendelian genetics, they would certainly be aware of the ease with which their favoured characteristic of semi-double florets disappeared!. This is a reason for emphasising the need for hand-pollination between selected cultivars to continue.

Most of the modern garden cultivars are very fertile, few only being recorded as fully sterile. Although cream-coloured cultivars, which are now much stronger growing and which can be obtained as a result of deliberate crosses (BASSETT, 1982) are relatively poor seed producers, this appears to be a case of stigma incompatibility rather than a problem at meiosis, since pollen produced by cream cultivars is viable and can be used to pollinate other cultivars including white. Like any character, fertility does vary and a modern breeder knows which cultivars to avoid when trying to produce a quantity of seed. This is in marked contrast to the sterility found in other known alloploids, which may set non-viable seed and propagation must depend on techniques designed to overcome this problem. A series of experiments designed to study the karyotypes of the semi-double garden elatum and to compare them with the wild-type $D$. elatum L., $D$ grandiflorum L. and hopefully, $D$. cheilanthum Fisch. from a number of sources are required. It is worth noting that seed of D. elatum L. has been offered to members of the Delphinium Society as $2 n$ and $4 n$. (1965) suggesting the occurrence in the wild of autotetraploids. Likewise other species have been listed as occasionally tetraploid, eg. $D$. hansenii (Greene) Greene. It may be that the garden elatum arose from the selection for larger flowers and increased sepal/petal number which might be expected to be seen with an increase in ploidy, and hybridising within this group of plants would maintain desirable recessive characters. Perhaps this is more likely than a chance species hybrid of elatum with grandiflorum or/and cheilanthum, followed by a further chance chromosome doubling of sterile diploid to a fertile tetraploid. If indeed natural tetraploids were already present in the population of plants grown by the early raisers, one possibility is that $D$. formosum hort. was actually a tetraploid of $D$. elatum which would certainly come true from seed. Application of modern techniques of chemotaxonomy and genetic engineering including restriction fragment polymorphism may lead to a more definite answer in the future, provided some financial support can be found.

The increasing cost of plant production coupled with a decrease in general garden size in the United Kingdom has resulted in near extinction for commercial breeding programmes and an increased contribution from a number of devoted amateurs. Encouragement for these 
enthusiasts has been the role of the Delphinium Society, enabling new cultivars to be brought to the notice of the general gardening public.

\section{The Delphinium Society}

The Delphinium Society has been in existence for over sixty years, being formed in 1928 by a number of keen delphinium specialists. Founded as the British Delphinium Society its objects were to encourage the production of new and improved cultivars, to collect and distribute information about all types of Delphiniums, to run trials and register named cultivars, to hold shows and to publish an annual journal. Although amateur membership was small at first, it continued to rise even though exhibiting at the first shows was beyond the scope of most small gardeners. Merging with the Northern Delphinium Society in 1936, it has remained the major focus for delphinium growers in Great Britain. The war years, 1939-1945, meant a cessation of flower growing while all concentrated on vegetables, but members remained loyal to the flower and to the Society and a few named cultivars survived.

However the years after the end of the war were difficult and were noted for the loss of specialist nurserymen. Between 1953-1959 under the influence of the late Ronald Parrett the Society was re-invigorated. The situation was no different in the United States where the American Delphinium Society was disbanded. Many American enthusiasts joined the British Delphinium Society and as the only specialist delphinium society in the world, the name was changed in 1956 to The Delphinium Society. Since then members have continued to join from all parts of the world, Australia, Canada, Japan, Southern Africa, New Zealand as well as the United States and from all of Europe.

Today, the objectives of the Society remain as before, the promotion of the Delphinium, and the annual Year Book is recognised as one of the best of the various specialist Society publications. It has always been the place for much unique information about aspects of Delphiniums and their cultivation and is invaluable as a reference source. In conjunction with the Royal Horticultural Society, new cultivars are submitted for assessment and for trial at the Wisley Gardens, where they may be compared with current cultivars already awarded the highest accolade of the R.H.S., a first class certificate for garden merit, the F.C.C. During late June/ early July the sight of several hundred flower spikes is like a magnet to visitors at the Trial ground. In addition to Shows at the R.H.S. Halls at Westminster, London, the Main Show is now held at the Wisley Gardens over a week-end, enabling members of the Society and other visitors to discuss and enjoy their delphiniums.

In the early years the firm of Blackmore and Langdon was responsible for the introduction of many noteworthy cultivars, but the number of recent introductions has been severely reduced due to financial considerations. The late Frank Bishop, another breeder of considerable repute was able to distribute his introductions through Bakers of Wolverhampton, now no longer in existence. A number of amateur breeders, members of the Society, started to replace the commercial breeders and included Ronald Parrett who exploited both material from Bishop and from Reinelt in the United States. The late Tom Cowan was the raiser of the well-known "Loch» series of show cultivars in the 1970s, while Roy Latty introduced some early dusky-pinks, line-bred by selection from Reinelts "Astolat» strain. Successful breeders at the present time who use hand-pollination include Duncan McGlashan, Clive Rowe and David Bassett, while there is now fresh interest from the nursery trade with Woodfield Brothers of Stratford-on-Avon and a number of growers in Holland. Much of this interest in Holland centres on the cut-flower market. The large garden elatum has never been popular as a cut-flower due to the its relatively short lifetime in water. The introduction of the technique used by commercial carnation growers of treatment for some hours in a solution of silver thiosulphate (STS) to lengthen the life of the cut flower, has a dramatic effect on delphiniums. 
They can now be used in flower arrangements with confidence and have a future in the cut-flower market. This may lead to a return to a spike of narrower proportions, more suitable for transport, especially by air to the United States.

The growing of different Delphinium species for garden use is still of interest to many members of the Society and the Society seed list tries to reflect this, but it is not easy to obtain reliable sources of seed. Use of species to form new races of garden delphiniums is the object of a few enthusiasts. Most garden elatums have no scent, or at least not a pleasing scent, and this is a disappointment to many members of the public who admire the flowers. Scent does occur in D. leroyi Franch, also unusual in that it is one of three species only known in Africa. It has been used by Dr. Legro in breeding experiments but not with the success seen in his red delphiniums. Use of the yellow $D$. zalil has long been thought the means by which a true yellow might be introduced. D. zalil, a diploid, is not easy to grow in Great Britain, resenting disturbance and spending much of the year as a dormant tuberous rootstock. Many years of patient selection would be needed using conventional genetic programmes to retain only the yellow colour and not the single flower or tuberous root. Maybe genetic engineering techniques inserting only the desired gene(s) offer a future pathway. Certainly continued breeding programmes designed to maintain and improve the form and length of the spike, length of flowering time, size and perfection of the floret and not least the colours available in the modern garden $D$. elatum must be encouraged. There is no doubt that the Delphinium Society has helped to maintain interest in this lovely flower, the undoubted «Queen of the Herbaceous Border».

\section{Bibliography}

Bassett, D. W. (1982). Crossing Both Ways. The Delphinium Society Year Book, 1982: 93-98.

Bishop, F. (1949). The Delphinium, Collins, London.

Genders, R. (1963). Delphiniums, London.

Knight, A. T. (1960). Bonita - A Postscript, The Delphinium Year Book, 1960: 45-46.

Legro, R. A. H. (1979). A Silver Thread Among the Gold, The Society Delphinium Society Year Book, 1979: 14-21.

Mehlquist, G. A. L. (1963). Some Experiences in Delphinium Breeding, The Delphinium Society Year Book, 1963: 10-19.

Parret, C. (1961). Delphiniums. Penguin Books, London.

PhILlIPS, G.A.R. (1933). Delphiniums; Their History and Cultivation, Eyre and Spottiswood, London.

Reinelt, F. (1964). History of the Modern Delphinium, Amer. Hort. Mag. 43: 98-103.

WILDE, E. I. (1930). Studies of the Genus Delphinium, Bull. Cornell Univ. Agric. Exp. St., Ithaca, New York, 519: 1-107. 